\section{MANAGEMENT OF PRIMARY PRIAPISM}

BY

\author{
J. OLDFIELD, M.B., B.S., F.R.C.S. \\ Senior Surgical Registrar, the Royal Victoria Infirmary, \\ Newcastle upon Tyne
}

Priapism is a painful erection of the penis without sexual desire. In most cases the erection is confined to the corpora cavernosa, and is due to the obstruction of the venous return through the dorsal veins of the penis. Many forms of treatment have been described and applied with varying degrees of success, but " few patients recovering from persistent priapism regain their pristine potency" (Hamilton Bailey, 1947).

The most common cause is primary phlebothrombosis, and it is thought that the initiating lesion may be trauma or persistent spasm of the erectile musculature during coitus. Most of these patients are young adults, and failure of complete resolution can have tragic consequences. The natural history of the condition is unpredictable. It may resolve after a variable period of time, sometimes a few hours, or, as in the case described by Tripe (1845), four months, without any impairment of function. It may, however, persist with subsequent organization and fibrosis of the corpora cavernosa.

Many treatments have been described which have had success in the hands of their authors, but subsequent experience in other hands has not been satisfactory. They have been well reviewed by Hamilton Bailey, and include the following: (1) division of the pudendal nerves, (2) division of the ischiocavernous muscles, (3) ligation of the dorsal arteries, (4) aspiration of the corpora cavernosa, (5) incision of the corpora cavernosa, (6) rectal diathermy, and (7) anticoagulant therapy. A new approach to the problem was described by Brody et al. (1957) with partial success in one case after forcible massage under general anaesthesia. In advocating this more conservative approach to the problem I would like to describe two cases which have been under my care.

\section{Case 1}

The patient, aged 32, was admitted to the Royal Victoria Infirmary, Newcastle upon Tyne, on December 30, 1953. He was on leave from the Army. On the evening before admission he had normal intercnurse with his wife. Later that night he was awakened with a painful erection of the penis, which was still present on admission to hospital. There was no history of previous episodes, injury, or venereal disease. He was a healthy young man with no other disability.

The penis was rigid and held at an acute angle to the abdominal wall. Movement of the slightest degree produced severe pain. The engorgement was limited to the corpora cavernosa, and he was able to pass urine with difficulty Investigation showed no evidence of neurological or blood disease.

Morphine $\frac{1}{4}$ gr. (16 mg.) was given six-hourly and intravenous heparin, 6,000 units at once and 3,000 units three-hourly. After 24 hours there was no change, but the discomfort was bearable, and this persisted for five days under heparin therapy. On the fifth day the degree of congestion had decreased considerably, and by the next day had completely resolved.

The penis remained flaccid, and later function was normal in all aspects.

\section{Case 2}

The patient, aged 37 , was admitted to hospital on September 2, 1958, with a painful erection which had been present for two days. There was no difficulty with micturition. For the past two years he had been having spontaneous erections, at intervals of one month, which would last approximately one hour before reduction. $\mathrm{He}$ had bathed the penis with cold water, but had been unable to increase the speed of resolution in any way. There was no history of venereal or urinary disease.

On examination he was seen to be a healthy man, not in excessive pain, and afebrile. The penis was engorged, and held at an acute angle to the abdominal wall. Movement produced severe pain.

Investigations.-Blood: Hb, $88 \% \quad(13 \quad$ g./100 ml. $)$; normochromic ; normocytic ; W.B.C., 7,800/c.mm (neutrophils $76 \%$, eosinophils $2 \%$, lymphocytes $18 \%$, monocytes $4 \%)$; W.R. and Kahn test, negative. Urine culture. negative. Intravenous pyelogram, normal.

Morphine 1/6 gr. (10 mg.) was given six-hourly, heparin 10,000 units intravenously, and heparin retard $2 \mathrm{ml}$. intramuscularly 12-hourly. After five days there was no change in the physical signs.

September 7.--Pudendal nerve block $2 \%$ lignocainediminution of pain only.

September 10.-Spinal anaesthetic. $10 \mathrm{ml}$. light cinchocaine. Level of anaesthesia D 6. No effect on physical signs. Under anaesthesia, aspiration and irrigation of the corpora cavernosa was carried out. Dark, viscid blood was obtained with slight decrease in turgidity of the corpora. This rapidly recurred.

September 12.-Leeches applied to the dorsal veins-no effect.

September 13.-General anaesthetic. Thiopentone $8 \mathrm{ml}$., suxamethonium $75 \mathrm{mg}$. This produced a slight decrease in tension. Both corpora were again aspirated and irrigated with saline, with slight improvement. By evening the priapism had completely recurred.

September 14-15.- Deep sedation, amylobarbitone sodium

3 gr. (0.2 g.) four-hourly-no effect.

September 15.-Phenindione therapy commenced.

September 22.--Local infiltration with $2 \%$ lignocainerelief of discomfort only.

September 29.-Pudendal block. $5 \mathrm{ml}$. "proctocaine" each side. No effect.

October 2.-Spinal anaesthetics ; $10 \mathrm{ml}$. light cinchocaine. Level of anaesthesia, D 6. This produced a definite decrease in turgidity of the corpora. On this occasion forcible massage was applied to the shaft of the penis, forcing blood from the glans to the root of the penis. This was continued for five minutes, and at the end of this time the penis was quite oruised and flaccid. It could be brought to an angle of 120 degrees to the abdominal wall. This improvement was maintained after the effects of the anaesthetic had passed off.

October 6.-Forcible massage repeated under general anaesthesia with marked improvement. At the end of the manipulation the penis was completely flaccid. The same evening the congestion had recurred, but a definite degree of improvement was maintained.

October 10.-Forcible massage under general anaesthesia with complete success; the flaccidity was maintained.

Four days later the patient was discharged home on phenindione, which was continued for one month. The improvement has been maintained, but for two months after discharge he was unable to produce an erection.

When reviewed on December 8 he was well satisfied with the result and was now able to have normal intercourse. The erection was, however, defective in that the right corpus cavernosum failed to fill satisfactorily, producing a deviation of the penis to the right. On examination the root of the right corpus cavernosum was found to be fibrotic. 


\section{Discussion}

The final cause of persistent priapism is thought to be thrombosis of the dorsal veins draining the corpora cavernosa into the pelvic plexus of veins. The initial cause may be spasm of the erectile musculature, or possibly trauma, which could occur during coitus. Thrombosis of the corpora appears to be delayed for some time, and this delay can be prolonged indefinitely by anticoagulant therapy. Resolution may occur in the early stage by relief of the muscular spasm. This is presumably what occurred in the second case in the earlier attacks. After thrombosis has occurred resolution can be achieved only by recanalization of the dorsal veins, and this, too, may occur spontaneously after a considerable time, as in the case quoted by Tripe (1845). If the thrombosis persists, the rational approach to the problem would appear to be a direct attack on the vein to perform a disobliterative operation. This would be a very difficult and uncertain procedure. The problem is simplified if the thrombus could be persuaded to move on into a part of the pelvic venous plexus where it does not produce such drastic effects. This is presumably what happens after forcible massage, the dorsal veins being cleared of thrombus, allowing adequate drainage to occur.

In our second case the disobliteration of the vein was produced after 30 days, and this resulted in a partial recovery of normal function. I feel that if the procedure had been attempted earlier a better result might have been possible.

\section{Summary}

Two cases of persistent priapism are presented. The first resolved after five days on anticoagulant treatment alone. The second partially resolved after 30 days on anticoagulant therapy followed by forcible massage of the penis under general anaesthesia.

It is suggested that this non-operative method of management should be tried in the early stages of the condition.

I thank Mr. D. C. Dickson for permission to publish the second case, and Mr. G. Y. Feggetter and Mr. S. Mottershead for their helpful criticisms.

\section{BIBLIOGRAPHY}

Bailey, H. (1947). Brit. J. Surg., 35, 298.

Brody, H. S., Lahr, P. A., and Carroll, W. A. (1957). J. Urol. (Baltimore), 78, 153.

Cave, W. H. (1943). Amer. J. Surg., 61, 305.

Hinman, F. (1914). Ann. Surg., 60, 689.

Johannesburg, P. B., and Donovan, H. (1930). Brit. J. Urol., 2, 382.

McKay, R. W., and Colston, J. A. C. (1928). J. Urol. (Baltimore), 19. 121.

Morson, C. (1934). Brit. med. J., 2, 249.

Riches, E. W. (1930). Brit. J. Urol., 2, 380.

Tripe, J. W. (1845). Lancet, 2, 8.

The Pakistan Medical Research Council has now established the quarterly Pakistan Journal of Medical Research. The chairman of the editorial'board is Dr. M. JAFAR, and the editor Dr. M. M. SiddiQ Husain. The overseas subscription rate is 24 Pakistan rupees ( $f 1$ 16s.) a year, and inquiries should be sent to the Editor-Secretary, Director, Bureau of Laboratories, Government of Pakistan, Karachi Cantt.
HAEMOGLOBIN H DISEASE WITH PERSISTENT HAEMOGLOBIN "BART'S" IN AN ORIENTAL JEWESS AND HER DAUGHTER

\section{A DUAL ALPHA-CHAIN DEFICIENCY OF HUMAN HAEMOGLOBIN}

BY

B. RAMOT, M.D.

Ch. SHEBA, M.D.

S. FISHER, M.D.

Tel Hashomer Hospital, Israel

J. A. M. AGER, M.B., B.S.

St. Thomas's Hospital, London

AND

H. LEHMANN, M.D., Sc.D., M.R.C.P., F.R.I.C. St. Bartholomew's Hospital, London

Haemoglobin $\mathbf{H}$ was discovered in 1955 (Rigas, Koler, and Osgood, 1955; Gouttas, Fessas, Tsevrenis, and Xefteri, 1955), and its appearance in the phentoype is associated with the inheritance of thalassaemia (Motulsky, 1956). Oriental Jews are known to harbour the thalassaemia gene, particularly those from Kurdistan (Schieber, 1945 ; Matoth, Shamir, and Freundlich, 1955). We can now report the finding of haemoglobin $\mathrm{H}$ disease (haemoglobin $\mathbf{H}$ thalassaemia) in a Babylonian (Iraqi) Jewess and her daughter. The case presents two further points of interest. There was a decreased glutathione stability of the red cells in the mother, and, in addition to haemoglobin $\mathbf{H}$, an abnormal foetal haemoglobin "Bart's" (Ager and Lehmann, 1958) was present in both mother and daughter.

\section{Case Report}

A 40-year-old Jewish woman from Bagdad was sent to the Tel Hashomer Hospital because of dizziness and increasing fatigue for the previous six months. There was no contributory history, and the patient had never been jaundiced. On physical examination the only positive findings were pallor and hepatosplenomegaly, both liver and spleen being palpable for two fingerbreadths below the costal margin. No skeletal abnormalities were found on $x$-ray survey.

\section{Blood Examination}

Plasma: serum proteins were normal in amount and distribution (paper electrophoresis). Serum lability (liverfunction) tests showed nothing abnormal. Serum bilirubin : total $1.1 \mathrm{mg} . / 100 \mathrm{ml}$., direct $0.4 \mathrm{mg} . / 100 \mathrm{ml}$. Serum iron $165 \mu \mathrm{g} . / 100 \mathrm{ml}$. White cells: total count $6,200 / \mathrm{c} . \mathrm{mm}$.; differential count normal. Red-cell count 4,540,000/c.mm.; haemoglobin 7.7 g. $/ 100 \mathrm{ml}$; P.C.V. $34 \%$; M.C.V. 75 cubic microns ; M.C.H. $17 \mu \mu \mathrm{g}$.; M.C.H.C. $23 \%$; reticulocytes $7.8 \%$. Inclusion bodies were seen in the red cells on incubation with brilliant cresyl blue. Osmotic fragility was reduced and the bone-marrow showed an erythrocytic hyperplasia. The stained smear (Fig. 1) showed marked poikilocytosis, many target cells, and 4 nucleated red cells per 100 white cells. Coombs test was negative. Glutathione stability was reduced: $27 \mathrm{mg}$. $/ 100 \mathrm{ml}$. red cells ; glucose-6phosphate dehydrogenase activity 9.1 OD units/g. haemoglobin (Szeinberg, Sheba, and Adam, 1958).

Haemoglobin.-The haemoglobin was examined by paper and starch electrophoresis, the first at $p \mathrm{H} 8.6$ and at $p \mathrm{H} \mathrm{6.5,} \mathrm{the} \mathrm{latter} \mathrm{at} p \mathrm{H} \mathrm{8.8.} \mathrm{On} \mathrm{paper} \mathrm{electrophoresis}$ three fractions were seen in the position of $A$, Bart's, and H (Fig. 2). On starch electrophoresis it was seen that 